\title{
EXPLORING THE SOCIOCULTURAL IMPEDIMENTS TO FEMALE IN GETTING HIGHER EDUCATION IN PUKHTUN SOCIETY \\ Younas Khan ${ }^{1 *}$, Fazal Hanan ${ }^{2}$, Abdullah $^{3}$, Habib ur Rahman ${ }^{4}$, Asad Ullah ${ }^{5}$
}

${ }^{1 *}$ Ph.D., Scholar, Department of Rural Sociology, The University of Agriculture Peshawar, Pakistan, and Lecturer in Sociology, Department of Sociology and Political Sciences, Bacha Khan University Charsadda, Pakistan; ${ }^{2}$ Assistant

Professor, Department of Sociology, FATA University, TSD Darra, NMD Kohat KP, Pakistan; ${ }^{3}$ Lecturer in Sociology, Department of Sociology and Political Sciences, Bacha Khan University Charsadda, Pakistan; ${ }^{4} \mathrm{Ph} . \mathrm{D} .$, Scholar, Department of Rural Sociology, The University of Agriculture Peshawar, Pakistan; ${ }^{5}$ M.Phil., Scholar, Department of Sociology, The University of Malakand Chakdara, Pakistan.

Email: ${ }^{1 *}$ youniskhan@bkuc.edu.pk, ${ }^{2}$ dr.hanan@fu.edu.pk, ${ }^{3}$ abdullah.soc@ @kuc.edu.pk, ${ }_{5}^{4}$ habibhay@gmail.com, 5 smasadjan@gmail.com

\section{Article History: Received on $19^{\text {th }}$ April 2021, Revised on $18^{\text {th }}$ May 2021, Published on $23^{\text {rd }}$ May 2021}

\begin{abstract}
Purpose of the study: This study was designed to explore the socio-cultural impediments to females getting higher education in ${ }^{1}$ pakhtun society.

Methodology: A cross-sectional quantitative research method was conducted in district Dir lower Pakistan. A wellstructured interviewed schedule (encompassing all the study attributes) was used for primary data collection from 375 female respondents after the pre-test procedure. The data were analyzed through descriptive statistics and inferential statistics $\left(\mathrm{x}^{2}\right.$ test) to ascertain the association between dependent (female higher education) and independent (sociocultural impediments) variables.
\end{abstract}

Principal Findings: Based on the study results, a significant association $(\mathrm{P}=0.000)$ was found between the dependent variable and sociocultural attributes; the prevalence of patriarchal norms $(\mathrm{P}=0.00)$, preferences of early marriages $(\mathrm{P}=0.00)$, fear of sexual harassment $(\mathrm{P}=0.00)$, parents carelessness $(\mathrm{P}=0.00)$, Parda (veiling for women and protecting their honour) and lack of decision-making power $(\mathrm{P}=0.00)$ impedes women from getting their higher education.

Applications of this study: Early marriage is a symbol of female exploitation under the man-made unwritten codes of conduct (Pukhtoonwali) which, should be banned through formal (legislation) and informal agencies (familial and religious) level; with a collaboration of educating female to ensure dethroning the partisan character in the form of patriarchal norms, which women faced since the dawn of the history. A slogan or any other campaign through mass media and print media is the order of the day. The government should ensure to play their role on macro and micro level to eliminate the negative stigmatization of women generally while in getting higher education particularly.

Novelty/Originality of this study: This study is an attempt to insight into the socio-cultural barriers to female attainment of higher education in pukhtun society through perceptional based study along with quantitative research designs to measure the association between the variables as mentioned above with an amalgamation of an addition to the existing stock of knowledge in the field of sociology of education.

Keywords: Early Marriages, Female Higher Education [FHE], Patriarchal Norms, Pukhtun Society.

\section{INTRODUCTION}

Education is derived from the Latin word "Educare", which means "to bring out" or "to nourish". Thus "education" is a sociological as well as the philosophical term which originates since the inception of humanity refers to a "learning process" (by formal or informal means) or sociologically entitled "socialization", which starts from birth and end with death. It is an ongoing process that occurs throughout our lifespan. Education is a systematic process through which a child or an adult acquire knowledge, experience, skills, and a good attitude. It makes an individual civilized, refined, cultured, and educated. Many scholars, philosophers, sociologist \& educationists put forwarded various definitions according to their own perspective which is education is the creation of a sound mind in a sound body (Aristotle), is the child development from within (Rousseau), and the capacity to feel pleasure and pain at the right moment (Plato) ( Khan Y et al., 2019a).

Women comprise half of the world population but are discriminated against in every sphere of life because of their gender identity as feminine evoked to more vulnerable in society (Anwar et al., 2014). Besides, according to the United Nations and world bank report conducted in 2011, disclosed that in Pakistan and Bangladesh the women education is negatively related to several factors, including household income, discrimination to educate the only son rather than girl,

\footnotetext{
${ }^{1}$ Pashtun, also spelled Pushtun or Pakhtun, Hindustani Pathan, Persian Afghan, Pashto-speaking people residing primarily in the region that lies between the Hindu Kush in northeastern Afghanistan and the northern stretch of the Indus River in Pakistan.
} 
conservatism, and negative attitudes from society to get an education (Fatima, 2011). Furthermore, according to the educational policy of Pakistan from 1998 to 2010, set a target to enroll 90 percent of children containing the age group (5-9 years). However, the target had not achieved due to political instability or lousy governance, insufficient utilization of resources, and illiteracy of parents, which provokes girls education with fewer preferences. Besides mostly in third world countries, the social position has become more excellent value due to the prevalence of patriarchal norms; male member is used as a sign of respect and dignity whereas the social status of a female is considered inferior. By birth and by the help of socialization male is considered as brave and enjoying all the rights and opportunities which they wish to, while at the same time girl are neglected from their fundamental rights since childhood thus resulting inferiority complex (Khan Y et al., 2019b; Rizvi, 1980). Still, gender-based discrimination has its existence since the inception of humanity, and the main factor in which the term gender is pinpoint is culture and societies through which male members are superior over female. Thus society socializes people to view that power is a masculine trait and powerlessness as a

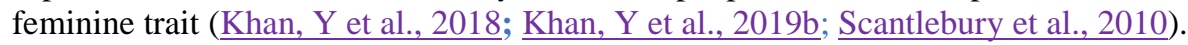

Education is directly associated with women empowerment and freedom in every walk of life (Velkoff, 1998). Only education itself is not a contributing factor of women empowerment because women empowerment by self is a multidimensional phenomenon, but still, education is the leading factor that evoked women empowerment (Noreen and Khalid, 2012). Besides, education plays a fundamental role in human capacity development and reasoning. Different researches claim that there is no tool for the development of any country rather than education. Similarly, with regards to educational benefits, as Nelson Mandella stressed on the importance of education in his famous quote "education is the most powerful weapon through which you can change the whole world" (Khan, 2007). Equally, women empowerment can be strengthening under getting higher education. There are various benefits of higher education which women may prevail when they get into it to become a role model for younger girls within a social system as well as become a wellknown mother or leader (Shaukat \& Siddiquah, 2015). Likewise, when women get the higher education, they can avail what they want in their lives in term of liberty, increased income level, increased social mobility, boost their self-esteem, knowledge, self-confidence, awareness of gender equity, improve analytical skills \& other phenomenal changes in all life dynamics (Graham, 2008; Maslak \& Singhal, 2008).

An educated woman can better wonderfully socialize her children and always help to deliver new values and ideas by socialization (Ram, 2004). Likewise, an educated female can perceive a better situation and the possibility of attaining it; she can realize what is within her reach and what she should do to improve. Napoleon once stated that "gives me an educated mother I will give you a civilized and educated nation" (Usha \& Sharma, 2001). Similarly, an educated female helps in the development of society, including economic productivity and higher family income (Nayak and Nair, 2005). But unfortunately, due to the prevalence of sociocultural climate, women are discriminated against and suffered from their fundamental rights in the Pakistani scenario (Khan, Y et al., 2018; Khan, Y et al., 2019b; Sen, 2001).

Likewise, from social science researches, it is concluded that gender role assigns to a particular member of society (male and female) by virtue of societal culture. It is a culture that dictates and marking the label of masculine or feminine. Generally, in less developed countries, culture considered women as a secondary source of citizenship while particularly in the Pakistani scenario. This discriminatory behavior may further open the doors for women to faced oppression and exploitation (Jalal \& Khan, 2008; Naz, 2011; Khan, 2007; Thomas et al., 2009; Shah,2008). Similarly, lack of educational institutions, traditionalism, parent carelessness, domestic responsibilities, and a small number of vocational training centres may provoke the girls to lag from education (Anwar et al., 2014; Khan, 2007; Maqsood, \& Raza, 2012). Besides women have limited access to get higher education and attain self status in the society by which society does not allow them as well as conservative beliefs of people like misunderstanding that education is only for male rather than female impede female from getting a higher education (Tembon, M and Fort, L. 2008).

\section{Objectives}

1. To explore the socio-cultural constraints to females in getting higher education.

2. To assess the level of association among socio-cultural constraints and female higher education in quantitative research design.

3. To suggest policy recommendations in light of the present study.

\section{METHODOLOGY}

Research Design \& Study area: A cross-sectional and quantitative study was conducted in the district [dist.] Dir lower. Concerning, the universe of the study, topography dist. Dir lower is located with Latitudes and Longitudes of $71^{\circ}, 31^{\prime}$ to $72^{\circ}, 14^{\prime}$ East \& $34^{\circ}, 37^{\prime}$ to $35^{\circ}, 07^{\prime}$ North correspondingly. It is approximately 2700 feet above mean sea level. Demographically dist. Dir is bounded by dist. Bajaur \& Afghanistan (West), dist. Chitral (North), dist. Malakand (South) \& dist. Swat (East) (Ullah, 2014). Besides, dist. Dir (Lower) consists of 7 tehsils, and each tehsil is divided into sub-union Council (UC), where each UC has been further categorized into village councils. However, the researcher purposively selected UC Balamabat due to the low educational attainment ratio of female in terms of higher education after conducting a pilot survey in Oct 2019. 
Research Sample \& Tools of Data Collection: According to the census report of 1998, the total population of UC Balamabat stood at 17790, resulting in 375-sample sizes as per Sekeran (2003) universal table of sample size distribution. Further, three Likert scales, namely "Yes, No \& Uncertain", was used. A well-structured interview schedule was used for the data collection procedure due to the prevalence of illiteracy ratio higher among female than male members of society (Khan Y et al., 2019). Moreover, data was collected with the help of 5 educated female enumerators from the female respondents, who were studying in different colleges and Dini madrasas (religious institution). Therefore, the researcher did not participate in data collection due to the prevalence of rigid socio-cultural barriers.

Data Analysis: After the collection of primary data, the researcher coded the collected information in Statistical Packages for Social Sciences "SPSS" version (20) for uni-variate and Bi-Variate analysis to analyze the results in terms of descriptive statistics (frequency and percentage distribution) and inferential statistics (Chi-square test). Chi-square test statistics is a method used to ascertain the association between dependent and independent variables as outlined by McCall and Robert (1975).

$$
\chi^{2}=\sum_{i=1}^{r} \sum_{j=1}^{c} \frac{\left(O_{i j}-e_{i j}\right)^{2}}{e_{i j}}
$$

The " $\mathrm{o}_{\mathrm{jk}}$ " was the observed frequency in the cell corresponding to the intersection of the $\mathrm{J}_{-}{ }^{\text {th }}$ row and $\mathrm{K}_{-}^{\text {th }}$ column, " $\mathrm{r}$ " the number of rows, and "c" the number of columns.

\section{RESULTS AND DISCUSSIONS}

\section{Perceptions \& Association between Sociocultural Constraints and Female Higher Education}

Table 1 shows the perception of respondents regarding the socio-cultural constraints to female higher education [FHE]. The table dismantled that, majority of the respondents, $67.7 \%$ believed that the patriarchal family system does not allow women to get access to higher education [HE] in the research area, $38.1 \%$ negated, and $8.3 \%$ of the respondents had no idea about the said statement. Also, a highly significant $(\mathrm{P}=0.000)$ association was found between the patriarchal system and female higher education. These findings attributed that the prevalence of patriarchal norms in Pukhtun society disrupted the equilibrium of society in all walk of life generally while the educational attainment of women particularly. Further, since the dawn of history, women are being suppressed and exploited under man-made rules and regulation by patriarchal norms. It is a social system where authority, power and decision making is only in the hand of a masculine member of a particular society. The male members used it as a tool for exploitation and suppression of women behaviours since inception as witnessed by Maqsood et al. (2012); Shah, (2008); Anwar et al. (2014); Khan et al. (2013).

Table 1: Frequencies and Percentage Distribution of Respondents regarding socio-cultural constraints to female in getting higher education as well as its Associations

\begin{tabular}{|c|c|c|c|c|c|}
\hline \multicolumn{6}{|c|}{$\begin{array}{l}\text { Different Sociocultural constraints Indicators (Statements) which restrict women from Getting Higher } \\
\text { Education with the collaboration of concerned association through cross-tabulation method }\left(\mathrm{x}^{2}\right)\end{array}$} \\
\hline \multicolumn{2}{|c|}{ Social Constraints } & \multicolumn{2}{|c|}{$\begin{array}{l}\text { Frequency \& Percentage } \\
\text { (Univariate Analysis) }\end{array}$} & \multirow{2}{*}{$\begin{array}{l}\text { Distribution } \\
\text { Uncertain }\end{array}$} & \multirow{2}{*}{\begin{tabular}{|l} 
Bivariate Analysis \\
Chi-Square Value
\end{tabular}} \\
\hline S.\# & Indicators/Statements & Yes & No & & \\
\hline 1 & Patriarchal family system & $201(53.6)$ & $143(38.1)$ & $31(8.3)$ & $\begin{array}{l}\chi^{2}=346.067 \\
(P=0.000)\end{array}$ \\
\hline 2 & Early marriage & $254(67.7)$ & $108(28.8)$ & $13(3.5)$ & $\begin{array}{c}\chi^{2}=261.205 \\
(\mathrm{P}=0.000)\end{array}$ \\
\hline 3 & The concept of purdah (veil) & $189(50.4)$ & $176(46.9)$ & $10(2.7)$ & $\begin{array}{c}\chi^{2}=369.443 \\
(\mathrm{P}=0.000)\end{array}$ \\
\hline 4 & $\begin{array}{l}\text { Traditionalism and conservative mind- } \\
\text { set }\end{array}$ & $195(52.0)$ & $149(39.7)$ & $31(8.3)$ & $\begin{array}{c}\chi^{2}=410.354 \\
(\mathrm{P}=0.000)\end{array}$ \\
\hline 5 & $\begin{array}{l}\text { Preference of male over women higher } \\
\text { education }\end{array}$ & $297(89.2)$ & $62(16.5)$ & $16(4.3)$ & $\begin{array}{c}\chi^{2}=199.232 \\
(\mathrm{P}=0.000)\end{array}$ \\
\hline 6 & Inferior societal status of female & $281(74.0)$ & $77(20.5)$ & $17(4.5)$ & $\begin{array}{c}\chi^{2}=355.548 \\
(\mathrm{P}=0.000)\end{array}$ \\
\hline 7 & Fear of sexual harassment & $283(75.5)$ & $84(22.4)$ & $8(2.1)$ & $\begin{array}{c}\chi^{2}=163.304 \\
(\mathrm{P}=0.000)\end{array}$ \\
\hline 8 & Coeducational system & $198(52.8)$ & $133(35.5)$ & $44(11.7)$ & $\begin{array}{l}\chi^{2}=265.207 \\
(\mathrm{P}=0.000)\end{array}$ \\
\hline 9 & Parents carelessness & $256(68.3)$ & $94(25.0)$ & $25(6.7)$ & $\begin{array}{c}\chi^{2}=199.232 \\
(\mathrm{P}=0.000)\end{array}$ \\
\hline 10 & $\begin{array}{l}\text { Limited involvement of girls in decision } \\
\text { making }\end{array}$ & $279(74.4)$ & $66(17.6)$ & $30(8.0)$ & $\chi^{2}=297.569$ \\
\hline
\end{tabular}


*Number in the table represent frequencies and number in parenthesis represent percentage proportion of the respondents

\section{Source: The author(s)}

Furthermore, $67.7 \%$ of the respondents proclaimed that early marriage impedes [FHE], $28.8 \%$ rejected, and $3.5 \%$ of the respondents had no idea about the above statement. Likewise, a highly significant association $(\mathrm{P}=0.000)$ was found between [FHE] and early marriage. Wedlock is a relationship between a husband and wife for the procreation of children and their socialization (Khan Y et al., 2019b). Based on these results, it could be concluded that the concept of early marriage still works under the name of Pukhtunwali (Pakhtun codes of conduct) that primarily caused a major hurdle in the way of female higher education. According to the report of UNICEP (2005) disclosed that in south Asia, nearly ten million young women married before the age of 18 years. Early marriage is a concept, which was practised mainly in third world countries generally while in Pakistan, particularly where most of the girls marry below 18 years of age. In Pukhtun society, women were socialized from childhood till marriage to stay modest and submissive in their dayto-day behaviours to maintain their statuesque. Besides, their movements were restricted when they grow up, and from the beginning, they were assigned household activities, which negatively affected their attainment of higher education in the future (Hussain et al., 2012; Anwar et al., 2014).

Equally, $50.4 \%$ of the respondents stated that purdah system (veil) impede [FHE]. However, $46.9 \%$ of the respondents negated, and $2.7 \%$ of the respondents were uncertain. Moreover, a significant association was found between purdah (veiling for women and protecting their honour) and [FHE]. It is concluded from the findings that strict rules and regulation in the form of dressing of veil may further lead women not to get education in the research area. Purdah comes under the jurisdiction of the Pukhtun code of conduct and may sometimes lead to fatalistic suicide (Sana, 2020a; Rukhsana et al., 2019).

Furthermore, the majority, $52.0 \%$ of the respondents, proclaimed that conservatism and traditional mindset impede [FHE], 39.7\% negated, and $8.3 \%$ were uncertain. Likewise, a highly significant association $(\mathrm{P}=0.000)$ was found between traditionalism and conservative mindset with [FHE]. This statement is nearly related to the patriarchal system where female are discriminated against socially, politically, economically, and politically by traditionalism and conservatism. Further, it is stated that traditional thinking of the peoples and conservative beliefs impedes [FHE] as witnessed by Temborn and Fort, 2008; Anwar et al., 2014; Fatima, 2011; Khan, 2007; \& Maqsood, \& Raza, 2012).

Moreover, $89.2 \%$ of the interviewees reported that preference of boys education over female impede [FHE], $16.5 \%$ criticized and $4.3 \%$ of the respondents had no idea about the above statement. Also, a highly significant $(\mathrm{P}=0.000)$ association was found between [FHE] and preference for boys over girls. It could be deduced from these findings that under the domain of Pukhtun society, some traits with regards to decision making and preferences dynamics were maleoriented; hence, affect [FHE] particularly (Sana, 2020a; Sana, 2020b). Likewise, Tembon and Fort (2008) also narrated that the common misconception to educate only boys while girls have to marry and look after household assignments negatively affect $[F H E]$ in Pakistan.

The table further illustrated that $74.9 \%$ of the respondents firmly in favour that, inferior social status or position of the female in society barricades $[F H E], 20.5 \%$ rejects, $4.5 \%$ of the respondents have no idea regarding the said statement. Likewise, an enormously significant association $(\mathrm{P}=0.000)$ was found between $[F H E]$ and female inferior social status. Similarly, Khan et al. (2013) and Rizvi (1980) also dismantled that, in the Pukhtun social system, the status or rank of women is considered inferior and have no concern/right to say with regards to educational, social, financial, political along with family dealings. The table further disclosed that $75.5 \%$ of the respondents were firmly in favour that fear from sexual harassment is a constraint to $[F H E]$. In comparison, $22.4 \%$ of the respondents rejected the statement, and $2.1 \%$ of the respondents had no idea regarding sexual harassment. Similarly, a highly significant association $(\mathrm{P}=0.000)$ was found between sexual harassment and $[F H E]$. Sexual violence among universities and colleges students is a universal phenomenon; as witnessed by the United Nations Women (2019) reported that 1 in every three women all over the world was either exposed to sexual/ physical violence by their own partner or by another person. Likewise, many research studies were conducted in terms of an employee in working affairs in general while among teachers and students in particular in educational institutions. However, the consequences of sexual violence/ harassment in higher education attainment are primarily concerned with psychological depression and organizational perspective such as drop out ratio is higher, lack of jobs in the market, student elopement, and female low down attendance in formal education (DFID, 2012; Voth, 2017; Henning et al. 2017; Fnais et al. 2014; McClelland et al. 2015; Chan et al. 2008; Willness, Steel, and Lee 2007).

Moreover, the table shows that $52.8 \%$ of the respondents believed that coeducation impeded [FHE], 35.5\% disclosed that coeducation was not a restraint to $[F H E]$, and $11.7 \%$ of the respondents had no idea. Likewise, a significant association $(\mathrm{P}=0.000)$ was found between coeducation and [FHE]. In the research area, Pashtun people followed their code of conduct called "Pukhtunwali", which does not permit a female to sit side by side with a male in educational institutions. Furthermore, $68.3 \%$ of the respondents thought that parent's carelessness regarding attainment of female higher education is a constraint to $[F H E], 25.1 \%$ of the respondents rejected, and $6.7 \%$ of the respondents had no idea 
regarding the said statement. Also, a highly significant association $(\mathrm{P}=0.000)$ was found between parent's carelessness and $[F H E]$. The above findings showed that religion Islam gives an equal right of getting an education (formal and informal) to every male and female member irrespective of their gender. As witnessed, the Prophet Muhammad (PBUH) commands that acquiring knowledge is obligatory for every man and women (Khan et al. (2013). However, due to sociocultural and human-made customs and traditions generally while Pukhtonwali particularly impedes a female education in pukhtun society.

Similarly, $74.4 \%$ majority of the interviewees believed that limited involvement of girls in the decision-making process is a constraint to female higher education $[F H E], 17.6 \%$ negated, and $8.0 \%$ of the respondents had no idea regarding this statement. Also, a highly significant association $(\mathrm{p}=0.000)$ was found between limited involvements of girls in the decision-making process with [FHE]. It could be concluded from the above findings that the respondents confessed the prevalence and domination of paternalistic culture in the study area (Khatak, n.d.). Similarly, Veer (2004) and Naz (2011) also found that women are considered as a threat to alteration of gender role and disruption of the societal equilibrium in future.

\section{CONCLUSION \& RECOMMENDATIONS}

A cross-sectional analysis was conducted in district Dir Lower with the sole purpose to assess the socio-cultural impediments to female getting higher education. The results of the study concluded that patriarchy, early marriages, coeducational system, fear of sexual harassment, parents carelessness, limited involvement of girls in the decisionmaking process, conservatism, purdah, preferences for male children's education over female impede the attainment of [FHE] in the study area. Moreover, patriarchy and early marriage as a symbol of female exploitation under man-made unwritten codes of conduct (Pukhtoonwali) should be banned through formal (Legislation) and informal agencies (Familial and Religious) level. Moreover, the separate educational institutions (Universities and colleges) for the female will resultantly overcome sexual harassment, which is a tumbling factor as well as eradication of religious and cultural discourse misunderstanding. Besides, $[F H E]$ will ensure to dethrone the partisan character in the form of patriarchal norms, which women faced since the dawn of history. A slogan or any other campaign through mass media and print media to raise awareness among society members, parents, and women, which could be used as a tool to eliminate the negative stigmatization of women generally while in getting $[\mathrm{HE}]$ mainly was put forward some of the recommendations in the light of study.

\section{STUDY LIMITATIONS}

This study was designed in a cross-sectional method; however, the longitudinal research could be valid and reliable due to the enormous amount of sample size selection. The responses might be unreliable due to human dynamism over time. Three Likert scales were used only where dealing with perceptions of the respondents regarding this topic must entail 5 or 7 Likert scales for validity and reliability. Keeping in view the universal nature of problems (higher education by female and challenges), the study was limited to sociocultural aspects in district Dir lower. However, the role of other institutional dynamics is the order of the day including economics, political, religious, and familial institution.

\section{ACKNOWLEDGEMENT}

All the researchers acknowledge wholeheartedly the sampled respondents for giving the information with the persistence of hospitality.

\section{AUTHORS CONTRIBUTION}

Younas Khan is the Principal and corresponding author of this article. He designed and proofread the article. Dr. Fazal Hanan was responsible for designing the statistical application of the whole process. Abdullah and Habib Ur Rahman assisted the data collection team with the collaboration of article and support of review in chronological order. Asad Ullah helped during questionnaire construction and helped in plagiarism elimination.

\section{REFERENCES}

1. Chan, D. K., Chow, S. Y., Lam, C. B., \& Cheung, S. F. (2008). Examining the job-related, psychological and physical outcomes of workplace sexual harassment: A meta-analytic review. Psychology of Women Quarterly, 32(4), 362-376. https://doi.org/10.1111/j.1471-6402.2008.00451.x

2. Carli, L. L. (1990). Gender, language, and influence. Journal of personality and social psychology, 59(5), 941. https://doi.org/10.1037/0022-3514.59.5.941

3. DFID Human Development Center. (2012). Helpdesk Report: Violence and Sexual Abuse in Schools in Afghanistan and Pakistan. https://www.heart-resources.org/wp-content/uploads/2012/11/Violence-and-Abusein-Schools-November-20121.pdf

4. Fatima, G. (2011). Female Education as a Determinant of Economic Growth: The Case Study of Pakistan. Contemporary Issues in Education Research, 4(11), 15-22. https://doi.org/10.19030/cier.v4i11.6485

5. Fnais, N., Soobiah, C., Chen, M. H., Lillie, E., Perrier, L., Tashkhandi, M., ... \& Tricco, A. C. (2014). Harassment and discrimination in medical training: a systematic review and meta-analysis. Academic Medicine, 89(5), 817-827. https://doi.org/10.1097/ACM.0000000000000200 
6. Farid, T., Anwar, M. N., Iqbal, S., Jan, M., \& Khattak, I. (2014). Socio-economic Problems Faced By Rural Women in Getting Higher Education (A Case Study of District Karak). International Asian Research Journal, 2(4), 31-40.

7. Hussain, I., Ahmed, M., Ahmad, S., Suleman, Q., \& Khalid, N. (2012). A Study to Investigate the Availability of Educational Facilities at the Secondary School Level in District Karak. Language in India, 12(10).

8. Henning, M. A., Zhou, C., Adams, P., Moir, F., Hobson, J., Hallett, C., \& Webster, C. S. (2017). Workplace harassment among staff in higher education: a systematic review. Asia Pacific Education Review, 18(4), 521539. https://doi.org/10.1007/s12564-017-9499-0

9. Jalal-ud-Din, M., \& Khan, M. (2008). Socio-economic and cultural constraints of women in Pakistan with special reference to Mardan district, NWFP province. Sarhad Journal of Agriculture, 24(3), 485-493.

10. Khan, S. (2007). Gender Issues in Higher Education in Pakistan, Islamabad.

11. Khan, H. A. M. A. D., Ali, A. K. H. T. A. R., Khan, R., \& Zia, Y. A. (2013). Social constraints to female higher education in Pakhtoon society. European Journal of Business and Social Sciences, 2(4), 25-31.

12. Khan. Y., Ullah. A., Din. F., Ahmad. ,S and Jaffar.T. (2019a). Economic constraints to female higher education in Pukhtun society. International Journal of Biology, Pharmacy and Allied Sciences, 8(5), 981-991. https://doi.org/10.31032/IJBPAS/2019/8.5.4715

13. Khan, Y., Shah, M., Ud-din, F., Ullah, Z., \& Rehan, S. (2018). Familial Impediments to Women Political Status in Pukhtun Society. Anthropol, 6(208), 2332-0915. https://doi.org/10.4172/2332-0915.1000208

14. Khan, Y., Shah, M., Ud-din, F., Khan, N., Ullah A., Rehan., and Ullah, Z. (2019b). Excluding women from political institution through educational deprivation. International Journal of Research and Innovation in Social Science, 3(1), 237-242. Retrieved from https://www.rsisinternational.org/virtual-library/papers/excludingwomens-from-political-institution-through-educational-deprivation/

15. Khatak, G. (n.d.). Attitudes of Parents Towards Contemporary Female Higher Education. Higher Education, Lifelong Learning and Social Inclusion, retrieved from https://files.eric.ed.gov/fulltext/ED567083.pdf

16. McClelland, G. T., Horne, M., Dearnley, C., Raynsford, J., \& Irving, D. (2015). Experiences and outcomes among undergraduate health professional higher education students with protected characteristics: disability, gender, and ethnicity. Journal of Psychological Issues in Organizational Culture, 6(1), 38-64. https://doi.org/10.1002/jpoc. 21168

17. Maslak, M. A., \& Singhal, G. (2008). The identity of educated women in India: confluence or divergence?. Gender and Education, 20(5), 481-493. https://doi.org/10.1080/09540250701829961

18. Maqsood, F., Maqsood, S., \& Raza, H. (2012). Getting higher education: Is it really a challenge for females in Pakistan?. Academic Research International, 2(3), 352. https://citeseerx.ist.psu.edu/viewdoc/download?doi= 10.1.1.1063.598\&rep=rep1\&type=pdf

19. Murphy Graham, E. (2008). Opening the black box: Women's empowerment and innovative secondary education in Honduras. Gender and Education, 20(1), 31-50. https://doi.org/10.1080/09540250701650623

20. Nayak. S., and Nair, J. (2005). Women Empowerment In India. Jaipur: Pointer Computers.

21. Noreen, G., \& Khalid, H. (2012). Gender empowerment through women's higher education: Opportunities and possibilities. Journal of Research and Reflections in Education, 6(1), 50-60.

22. Naz, A., \& Ahmad, W. (2012). Sociocultural impediments to women political empowerment in Pakhtun society. Academic Research International, 3(1), 163.

23. Ram, D. S. (Ed.). (2004). Women: Emergence of New Ideology. Commonwealth.

24. Rizvi, F. (1980). Background of vocational education for girls. The national conference on critical issues concerning women in education, Women Div. Govt. of Pakistan, Islamabad: 4

25. Sen, A. (2001). Improving gender equality in Pakistan: Small steps to date, large strides ahead. Retrieved from http://siteresources.worldbank.org/PAKISTANEXTN/Resources/293051-1146639350561/CGA-Chapter-1pdf

26. Shah, S., \& Sobehart, H. (2008). Women and educational leadership in a Muslim society. Women leading education across the continents: Sharing the spirit, fanning the flame, 344-381.

27. Scantlebury, K., Kahle, J. B., \& Martin, S. N. (Eds.). (2010). Re-visioning Science Education from Feminist Perspectives: Challenges, Choices, and Careers, 3. Sense Publishers. https://doi.org/10.1163/9789460910869

28. Shaukat, S., \& Pell, A. W. (2015). Personal and social problems faced by women in higher education. $F W U$ Journal of Social Sciences, 9(2), 101.

29. Tembon, M. M., \& Fort, L. (Eds.). (2008). Girl's education in the 21st century: Gender equality, empowerment and growth. The World Bank. https://doi.org/10.1596/978-0-8213-7474-0

30. Thomas, D. M., Love, K. M., Roan-Belle, C., Tyler, K. M., Brown, C. L., \& Garriott, P. O. (2009). Selfefficacy, motivation, and academic adjustment among African American women attending institutions of higher education. The Journal of Negro Education, 159-171.

31. UNICEF. (2005). Early Marriage: A harmful traditional practice. New York: United Nations.

32. Usha, S., \& Sharma, M.B.(2001). Women and higher education”. New Delhi: Commonwealth Publishers.

33. Ullah, S., Javed, W., Rasheed, B., Jamal, Q., Aziz, F.,. (2014). Assessment of groundwater quality of district Dir Lower Pakistan. International Journal of biosciences, 4 (8), 248-255. Retrieved from https://www.researchgate.net/publication/261835814_Assessment_of_groundwater_quality_of_district_Dir_Lo wer_Pakistan 
34. UN Women. (2019). Progress of the World's Women 2019-2020. https://data.unwomen.org/progress-of-theworlds-women

35. Velkoff, V. A. (1998). Women of the world: Women's education in India. US Department of Commerce, Bureau of the Census, International Programs Center WID/98-1.

36. Voth Schrag, R. J. (2017). Campus-based sexual assault and dating violence: A review of study contexts and participants. Affiliate, 32(1), 67-80. https://doi.org/10.1177/0886109916644644

37. Veer, A. (2004). Modern Education for New Generation. New Delhi: Anmol Publications.

38. Willness, C. R., Steel, P., \& Lee, K. (2007). A meta-analysis of the antecedents and consequences of workplace sexual harassment. Personnel Psychology, 60(1), 127-162. https://doi.org/10.1111/j.1744-6570.2007.00067.x 